Article

\title{
Environment-Sensitive Fluorescence of 7-Nitrobenz-2-oxa-1,3-diazol-4-yl (NBD)-Labeled Ligands for Serotonin Receptors
}

\author{
Parijat Sarkar $^{1} \mathbb{D}$, Kaleeckal G. Harikumar ${ }^{1,+}$, Satinder S. Rawat ${ }^{1, \ddagger}$, Sanjib Das ${ }^{2} \mathbb{D}$, Tushar K. Chakraborty ${ }^{2, \S}$ \\ and Amitabha Chattopadhyay ${ }^{1, *(D)}$ \\ 1 CSIR-Centre for Cellular \& Molecular Biology, Uppal Road, Hyderabad 500 007, India; \\ parijat@ccmb.res.in (P.S.); harikumarkg@mayo.edu (K.G.H.); satinderrawat10@gmail.com (S.S.R.) \\ 2 CSIR-Indian Institute of Chemical Technology, Uppal Road, Hyderabad 500 007, India; \\ sanjib.das@glenmarkpharma.com (S.D.); tushar@iisc.ac.in (T.K.C.) \\ * Correspondence: amit@ccmb.res.in; Tel.: +91-40-2719-2578 \\ + Present Address: Department of Molecular Pharmacology and Experimental Therapeutics, Mayo Clinic, \\ Scottsdale, AZ 85259, USA. \\ $\ddagger \quad$ Present Address: Taysha Gene Therapies, 3000 Pegasus Park Drive, Suite 1430, Dallas, TX 75247, USA. \\ $\S$ Present Address: Department of Organic Chemistry, Indian Institute of Science, Bengaluru 560 012, India.
}

\section{check for}

updates

Citation: Sarkar, P.; Harikumar, K.G.; Rawat, S.S.; Das, S.; Chakraborty, T.K.; Chattopadhyay, A. EnvironmentSensitive Fluorescence of

7-Nitrobenz-2-oxa-1,3-diazol-4-yl (NBD)-Labeled Ligands for Serotonin Receptors. Molecules 2021, 26, 3848. https://doi.org/10.3390/molecules 26133848

Academic Editors: Raffaele Capasso and Marcello Leopoldo

Received: 20 April 2021

Accepted: 21 June 2021

Published: 24 June 2021

Publisher's Note: MDPI stays neutral with regard to jurisdictional claims in published maps and institutional affiliations.

Copyright: (C) 2021 by the authors Licensee MDPI, Basel, Switzerland. This article is an open access article distributed under the terms and conditions of the Creative Commons Attribution (CC BY) license (https:/ / creativecommons.org/licenses/by/ $4.0 /$ )
Abstract: Serotonin is a neurotransmitter that plays a crucial role in the regulation of several behavioral and cognitive functions by binding to a number of different serotonin receptors present on the cell surface. We report here the synthesis and characterization of several novel fluorescent analogs of serotonin in which the fluorescent NBD (7-nitrobenz-2-oxa-1,3-diazol-4-yl) group is cova-

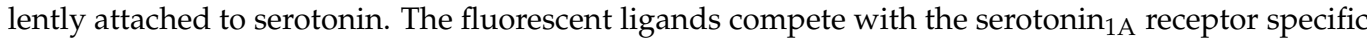
radiolabeled agonist for binding to the receptor. Interestingly, these fluorescent ligands display a high environmental sensitivity of their fluorescence. Importantly, the human serotonin ${ }_{1 \mathrm{~A}}$ receptor stably expressed in $\mathrm{CHO}-\mathrm{K} 1$ cells could be specifically labeled with one of the fluorescent ligands with minimal nonspecific labeling. Interestingly, we show by spectral imaging that the NBD-labeled ligand exhibits a red edge excitation shift (REES) of $29 \mathrm{~nm}$ when bound to the receptor, implying that it is localized in a restricted microenvironment. Taken together, our results show that NBD-labeled serotonin analogs offer an attractive fluorescent approach for elucidating the molecular environment of the serotonin binding site in serotonin receptors. In view of the multiple roles played by the serotonergic systems in the central and peripheral nervous systems, these fluorescent ligands would be useful in future studies involving serotonin receptors.

Keywords: NBD; serotonin; serotonin ${ }_{1 \mathrm{~A}}$ receptor; confocal microscopy; spectral imaging; REES

\section{Introduction}

Serotonin (5-hydroxytryptamine) is a biogenic amine, rather serendipitously discovered $\sim 70$ years back [1], that acts as a neurotransmitter. Serotonin is localized in diverse regions both in the central and peripheral nervous systems [2]. It is found in organisms that span a wide evolutionary range, from humans to species with primitive nervous systems such as worms [3,4], and mediates a variety of physiological responses in distinct cell types. Signaling mediated by serotonergic systems plays a crucial role in the initiation and regulation of several behavioral and cognitive functions that include sleep, pain, depression, sexual activity, alcohol abuse, and learning [5-10]. Dysfunctional serotonergic signaling has been implicated in the etiology of mental disorders such as schizophrenia, depression, suicidal behavior, infantile autism, and obsessive-compulsive disorder [11-13]. Signaling via serotonin is mediated by binding of serotonin to specific receptors on the cell surface, which are pharmacologically categorized into many groups [4,14-17]. A majority of serotonin receptors belong to the superfamily of seven transmembrane domain 
G protein-coupled receptors (GPCRs) $[4,16,18]$. Amongst the members of the serotonin receptor family, the serotonin ${ }_{1 \mathrm{~A}}$ receptor subtype is the most extensively studied GPCR for a variety of reasons $[15,19-21]$.

We previously showed that the intrinsic fluorescence properties of serotonin are dependent on its ionization state [22]. Our results showed that the fluorescence of native serotonin (as monitored by intensity, emission maximum, and fluorescence lifetime) is $\mathrm{pH}$-dependent. Further, since the ligand binding site for serotonin receptors is localized in the transmembrane core of the receptor, we monitored serotonin fluorescence in various nonpolar media in order to investigate the possibility of monitoring ligand binding in a sensitive and non-invasive way using the native fluorescence of serotonin. However, we found that the native fluorescence of serotonin is not ideally suited for this purpose due to a number of reasons. First, serotonin fluorescence was not found to be solvatochromic, i.e., not sensitive to its environment (as opposed to its parent fluorophore tryptophan, which shows large degree of solvatochromism). As a result, when the polarity of the environment in which serotonin was dissolved was changed, the corresponding changes in various fluorescence parameters were minimal or negligible. An additional problem arises due to the fact that serotonin absorbs and emits in the UV region of the spectrum. This makes serotonin fluorescence unsuitable for microscopy-based applications, since the sensitivities of most detectors for fluorescence microscopy fall off in the UV region. More importantly, many optical components of the microscope, unless specifically designed for UV transmission, absorb strongly in this wavelength range [23]. In addition, serotonin fluorescence has considerable overlap with the tryptophan fluorescence emitted by proteins, which could give rise to additional complications.

An extensively used fluorophore in biochemical, biophysical, and cell biological studies is the NBD (7-nitrobenz-2-oxa-1,3-diazol-4-yl) group [24,25]. The NBD group fluoresces in the visible region, and the excitation wavelength is compatible for excitation by laser sources often used for confocal microscopy, imaging, and cell sorting. NBD-labeled lipids are widely used as fluorescent analogs of native lipids in model and biological membranes to probe a wide range of processes [24-32]. The fluorescent NBD moiety harbors several desirable characteristics, which makes it an excellent probe for both spectroscopy and microscopy-based approaches. NBD exhibits extremely weak fluorescence in water and, when transferred to a hydrophobic medium, it fluoresces brightly in the visible range and shows a high sensitivity to its microenvironment [25,33-38]. In addition, the fluorescence lifetime of the NBD group is highly sensitive to the polarity of the surrounding environment [35,39-41]. NBD is moderately photostable, and NBD-labeled lipids are known to mimic endogenous lipids in studies of intracellular lipid transport [42-49].

In this paper, we report the synthesis and application of several novel fluorescent analogs of serotonin in which we have covalently attached the fluorescent NBD group to serotonin and evaluated their binding properties. The chemical structures of the fluorescent NBD-labeled analogs of serotonin are shown in Figure 1. In this work, we carried out competition binding and live cell fluorescence imaging of Chinese hamster ovary (CHO-K1) cells stably expressing the human serotonin $n_{1 \mathrm{~A}}$ receptor bound to these analogs. In addition, we monitored the solvatochromic properties (i.e., the sensitivity of fluorescence parameters to the environment) of these derivatives using both spectroscopy and microscopic (spectral imaging) approaches in order to assess the usefulness of these analogs in faithfully reporting the environment of the binding site. Our results show that these novel NBD analogs of serotonin represent useful probes to monitor the localization of serotonin receptors and their interactions with ligands. 
<smiles>C[C@H](NCCc1c[nH]c2ccc(O)cc12)C(=O)N[C@@H](C)c1ccc([N+](=O)[O-])c2nonc12</smiles>

Analog I : Ala-NBD serotonin<smiles>O=C(CNc1ccc([N+](=O)[O-])c2nonc12)NCCc1c[nH]c2ccc(O)cc12</smiles>

Analog II : Gly-NBD serotonin<smiles>O=C(NCCc1c[nH]c2ccc(O)cc12)[C@H](Cc1ccccc1)Nc1ccc([N+](=O)[O-])c2nonc12</smiles>

Analog III : Phe-NBD serotonin

Figure 1. Chemical structures of the fluorescent NBD-labeled analogs of serotonin used in this study. The fluorophore (NBD) is shown in red, serotonin is shown is blue, and the linker amino acid is depicted in green.

\section{Results}

\subsection{Design of the Fluorescent Analogs of Serotonin}

Agonists for serotonin receptors are chemically heterogeneous and belong to diverse chemical classes. However, a common structural feature shared by them is a basic amino group and an aromatic ring that usually has a hydroxyl (or methoxy or carbamoyl) group that could potentially form hydrogen bonds [50]. Serotonin, the natural agonist to serotonin receptors, consists of two reactive groups, the phenolic hydroxyl group and the primary amine group. Molecular modeling studies showed that the hydroxyl group is directly involved in binding to serotonin receptors by interacting with serine and threonine residues present in some of the transmembrane helices [50-52]. In addition, it was previously reported that the serotonin $\mathrm{A}_{1 \mathrm{~A}}$ receptor favors ligands with a hydrogen bond acceptor in a position corresponding to the hydroxyl group in serotonin [53,54]. We therefore decided to covalently attach the fluorescent NBD group to serotonin with the reactive amine group without modifying the hydroxyl group in order to not influence the binding properties (see Figure S1). The NBD group is covalently attached to serotonin through an amino acid derived short spacer arm to impart a degree of flexibility to the fluorescent analogs for efficient interaction between the ligand and the receptor without any hindrance due to steric constraints (Figure 1). It should be noted here that the primary amine group of

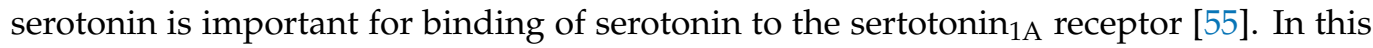
context, the chemical transformation of a basic primary amine into an amide deserves comment. Recent studies have shown that low basicity ligands for serotonin receptors, including the serotonin ${ }_{1 \mathrm{~A}}$ receptor, do exist [56,57], and this validates the design of our NBD-labeled probes using the reactive amine group. This could account for some loss in affinity of these ligands for the serotonin ${ }_{1 \mathrm{~A}}$ receptor (see later). 


\subsection{Competition Binding of the Fluorescent Ligands to Serotonin ${ }_{1 A}$ Receptors}

Among the subtypes of serotonin receptors, the $G$ protein-coupled serotonin ${ }_{1 A}$ receptor is the most well-studied receptor for various reasons [15,19-21]. One of the major reasons is the early availability of a ligand (8-OH-DPAT) with high selectivity that permits thorough pharmacological, biochemical, and physiological characterization of the serotonin $_{1 \mathrm{~A}}$ receptor $[58,59]$. The interactions of the fluorescent analogs of serotonin with serotonin $_{1 \mathrm{~A}}$ receptors stably expressed in $\mathrm{CHO}-\mathrm{K} 1$ cells were determined by assessing their ability to compete with the radiolabeled $\left[{ }^{3} \mathrm{H}\right] 8-\mathrm{OH}-\mathrm{DPAT}$ (a specific agonist for the serotonin $_{1 \mathrm{~A}}$ receptor) for binding to the receptor. The affinities of the fluorescent ligands were determined by competition binding experiments using the NBD-labeled serotonin analogs (I-III, see Figure 1). The displacement curves of $\left[{ }^{3} \mathrm{H}\right] 8-\mathrm{OH}-\mathrm{DPAT}$ by various fluorescent ligands are shown in Figure 2. We used unlabeled serotonin as a control in these experiments. Figure 2 shows that the fluorescent ligands were able to competitively inhibit the labeled agonist $\left[{ }^{3} \mathrm{H}\right] 8-\mathrm{OH}-\mathrm{DPAT}$ and exhibited characteristic displacement patterns. The inhibition constant $(\mathrm{Ki})$ and half maximal inhibition concentrations $\left(\mathrm{IC}_{50}\right)$ values for the NBD-labeled fluorescent ligands are shown in Table 1. While analogs I and II show similar displacement patterns (as judged by similarity in their $\mathrm{IC}_{50}$ and $\mathrm{K}_{\mathrm{i}}$ values), analog III shows somewhat less affinity, probably due to the presence of the bulky phenyl group. In general, analog I appeared to be the most potent analog, as apparent from competition binding assays (See Figure 2 and Table 1). The methyl group in analog I could provide enough hydrophobicity for efficient partitioning into the membrane where the binding site is located (see below).

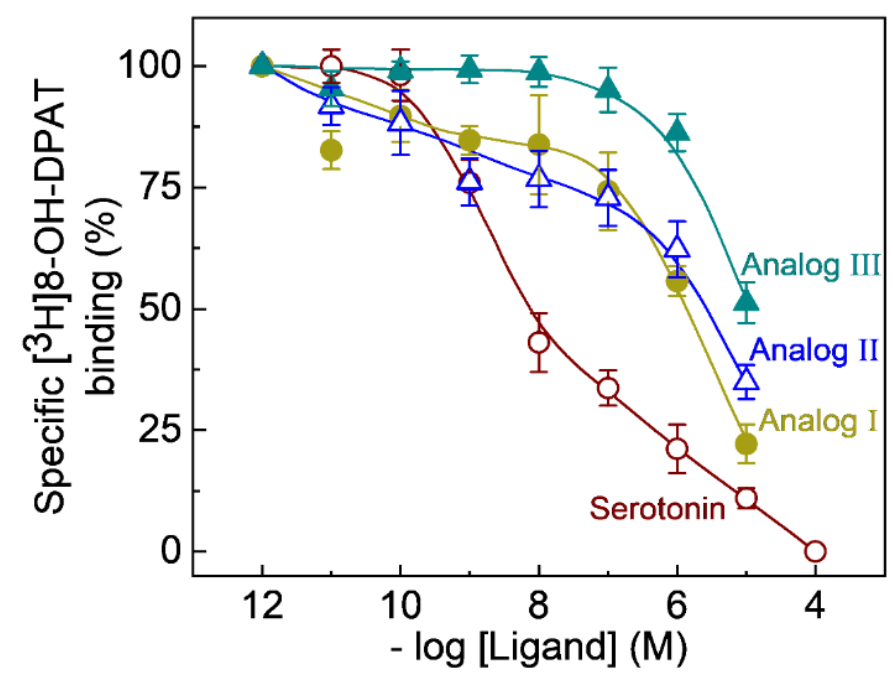

Figure 2. Competition binding of fluorescent NBD-labeled serotonin ligands to the human serotonin $_{1 \mathrm{~A}}$ receptor stably expressed in $\mathrm{CHO}-\mathrm{K} 1$ cells. Radioligand binding assays were carried out with $\left[{ }^{3} \mathrm{H}\right] 8-\mathrm{OH}-\mathrm{DPAT}$ in the presence of a range of concentrations (from $10^{-12}$ to $10^{-4} \mathrm{M}$ ) for serotonin $(\bigcirc)$ and NBD-labeled analogs I $(\bullet)$, II $(\Delta)$ and III $(\Delta)$. Values of specific binding measured in the presence of fluorescent analogs are expressed as a percentage of total binding obtained at the lowest concentration of the competing ligand. The curves represent nonlinear regression fits to the experimental as described in the Supplementary Material. Data shown are means \pm SE from five independent experiments. Nonspecific binding was determined in the presence of $10^{-4} \mathrm{M}$ unlabeled serotonin in each case. $K_{i}$ values were determined according to Cheng and Prusoff [60] and the average values are listed in Table 1. See Materials and Methods for other details. 
Table 1. $\mathrm{IC}_{50}$ and $\mathrm{K}_{\mathrm{i}}$ values of fluorescent NBD-labeled serotonin analogs for binding to serotonin $_{1 \mathrm{~A}}$ receptors stably expressed in CHO-K1 cells ${ }^{\mathrm{a}}$.

\begin{tabular}{ccc}
\hline NBD-Labeled Analogs & IC $_{\mathbf{5 0}}(\boldsymbol{\mu M})$ & $\mathbf{K}_{\mathbf{i}}(\boldsymbol{\mu M})$ \\
\hline I & $1.74 \pm 0.44$ & $1.41 \pm 0.36$ \\
II & $3.43 \pm 1.73$ & $3.15 \pm 1.41$ \\
III & $13.70 \pm 3.36$ & $11.15 \pm 2.73$ \\
\hline
\end{tabular}

a The $\mathrm{IC}_{50}$ and apparent dissociation constants $\left(\mathrm{K}_{\mathrm{i}}\right)$ values shown in the table represent the means \pm SE of duplicate points from five independent experiments. $K_{\mathrm{i}}$ for the fluorescent ligands were calculated as described in the Supplementary Material [61]. See Materials and Methods for other details.

\subsection{Fluorescence Characteristics of the Analogs}

The fluorescence emission spectra of NBD-labeled analogs of serotonin in various solvents are shown in Figure 3. The serotonin binding site in serotonin receptors is located inside the core of the transmembrane region where the microenvironmental polarity experienced by the ligand would be significantly lower relative to that in the bulk aqueous phase $[50,52-55,62]$. In order to assess the usefulness of the fluorescent ligands in such an environment, solvents were chosen, which are less polar than water (see Table 2). The fluorescence characteristics of NBD-labeled serotonin analogs in solvents of lower polarity are shown in Figure 3 and Table 2. The data show that in solvents of very low polarity (such as tetrahydrofuran), the fluorescent ligands show a significant enhancement of fluorescence. This enhancement of fluorescence intensity was accompanied by a concomitant blue shift of the emission maximum. Taken together, our results show that the environmental sensitivity displayed by the NBD-labeled serotonin analogs is in sharp contrast to the intrinsic fluorescence of serotonin, which shows little environmental sensitivity [22].

Table 2. Solvent effects on the fluorescence characteristics of NBD-labeled serotonin analogs.

\begin{tabular}{ccccccccc}
\hline & & \multicolumn{3}{c}{ Emission Maximum (nm) } & \multicolumn{3}{c}{ Relative Intensity $^{\mathbf{c}}$} \\
\cline { 3 - 8 } Solvents & $\begin{array}{c}\text { Dielectric } \\
\text { Constant }\end{array}$ & \multicolumn{3}{c}{ Analog } & & \multicolumn{3}{c}{ Analog } \\
\cline { 3 - 8 } & & I & II & III & I & II & III \\
\hline Tetrahydrofuran & 7.58 & 520 & 520 & 525 & 3.7 & 2.4 & 4.8 \\
Isopropanol & 18.30 & 520 & 524 & 525 & 1.3 & 0.9 & 1.8 \\
Acetone & 20.70 & 520 & 523 & 526 & 2.9 & 1.9 & 3.6 \\
Ethanol & 24.30 & 520 & 526 & 528 & 1.2 & 0.9 & 1.7 \\
Methanol & 32.63 & 526 & 530 & 532 & 1.0 & 0.6 & 1.3 \\
Dimethyl & 46.45 & 541 & 540 & 542 & 1.0 & 1.0 & 1.0 \\
sulfoxide & & & & & & & \\
\hline
\end{tabular}

$\overline{\mathrm{b}}$ From [63]. ${ }^{\mathrm{c}}$ Calculated by measuring fluorescence intensity at the respective emission maximum upon excitation at $465 \mathrm{~nm}$ and normalized to the fluorescence intensity in dimethyl sulfoxide.

\subsection{Specific Fluorescent Labeling of Serotonin ${ }_{1 A}$ Receptors with NBD-Labeled Serotonin Analog}

The NBD-labeled serotonin analog I was used to further explore specific labeling of $\mathrm{CHO}-\mathrm{K} 1$ cells heterologously expressing the human serotonin ${ }_{1 \mathrm{~A}}$ receptor. Importantly, we earlier reported that the human serotonin ${ }_{1 \mathrm{~A}}$ receptor heterologously expressed in these cells preserves functional characteristics of the native receptor (such as ligand binding and G-protein coupling [64]). A representative confocal micrograph obtained by labeling of human serotonin ${ }_{1 \mathrm{~A}}$ receptors expressed in $\mathrm{CHO}-\mathrm{K} 1$ cells with the NBD-labeled serotonin analog I is shown in Figure 4a. Figure 4b shows untransfected CHO-K1 cells display no labeling when incubated under identical conditions as in transfected cells. These results suggest that the nonspecific labeling of the analog was negligible. Importantly, labeling by the NBD-serotonin analog I was competed out in cells incubated with the same concentration of fluorescent ligand (as in Figure 4a) in the presence of an excess of unlabeled serotonin (see Figure 5a). The figure shows that the fluorescent signal from NBD was lost within $\sim 10 \mathrm{~min}$ of incubation with unlabeled serotonin. In a control experiment, we imaged cells labeled with NBD-serotonin analog I in the presence of an equal volume 
of Milli-Q water to rule out any photobleaching related artifacts that could arise due to prolonged imaging (Figure $5 b$ ). Taken together, these results suggest the specific nature of labeling by the NBD-serotonin analog I in CHO-K1 cells.

(a)

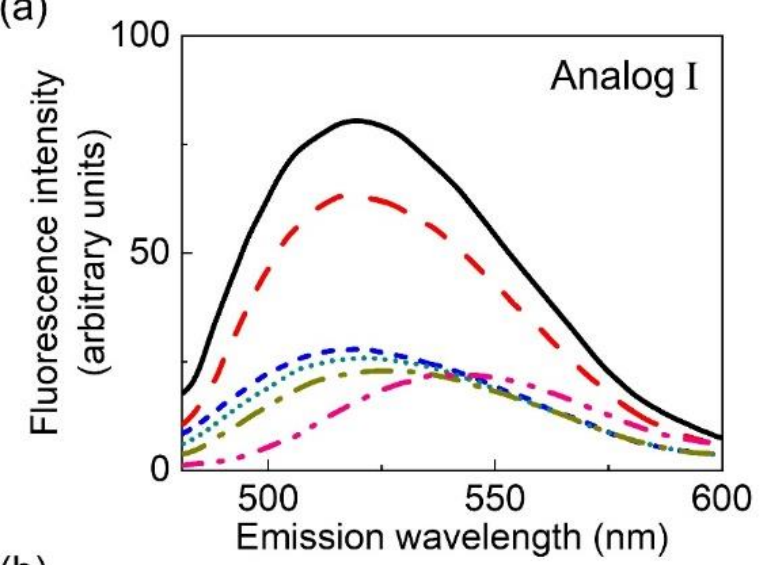

(b)
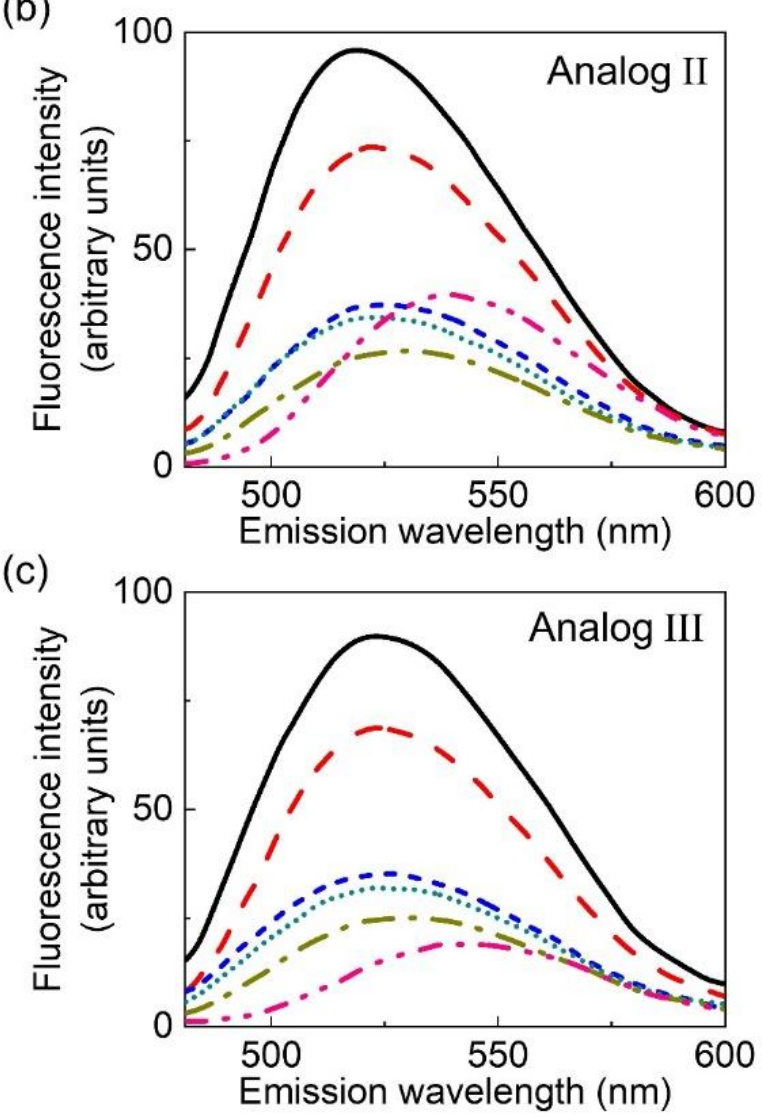

Figure 3. Fluorescence emission spectra of NBD-labeled analogs of serotonin (I-III) in solvents of varying polarity shown in panels $(\mathbf{a}-\mathbf{c})$, respectively. The solvents used were tetrahydrofuran (-), acetone (-), isopropanol (-), ethanol (......), methanol (- ${ }_{-}$), and dimethyl sulfoxide (-- - $)$. The concentration of the NBD analogs of serotonin used was $8 \mu \mathrm{M}$ and the excitation wavelength used was $465 \mathrm{~nm}$ in all cases. See Materials and Methods for other details.

\subsection{NBD Group Senses Slow Solvent Relaxation around the Ligand Binding Pocket in the Serotonin $_{1 A}$ Receptor}

Previous work from our laboratory and recent evidence from crystallographic data on the serotonin $n_{1 \mathrm{~A}}$ receptor suggest that the serotonin binding pocket is localized in the interfacial region of the membrane [52,55]. Interestingly, many fluorescent molecules lo- 
calized at the interfacial region of the membrane show red edge excitation shift (REES) due to the unique physicochemical properties of this region $[65,66]$. REES is a sensitive approach that could be utilized for monitoring the environment and dynamics around a fluorophore in complex biological systems [65-69]. REES is predominantly observed when polar fluorophores are present in motionally constrained media such as viscous solutions or condensed phases (e.g., proteins and membrane) in which the solvent dipolar relaxation time around a fluorophore is comparable to or longer than its fluorescence lifetime. In experimental terms, REES is defined as the shift in the wavelength of fluorescence emission maximum toward higher wavelengths due to a shift in the excitation wavelength toward the red edge of the absorption band. This arises as a result of slower rates of solvent reorientation (relaxation) in the immediate vicinity of an excited state fluorophore, which is dependent on motional restriction imposed on the solvent molecules around the fluorophore. As a result, REES can be effectively used to monitor the organization and dynamics of the environment (which is represented by the relaxing solvent (water) molecules), using the fluorophore merely as a reporter group. Although the bulk of REES analysis has used spectroscopic (cuvette-based) measurements, we utilized confocal microscopy based high resolution spectral imaging to monitor the REES of the NBD analog I bound to serotonin $_{1 \mathrm{~A}}$ receptor in live $\mathrm{CHO}-\mathrm{K} 1$ cells.

(a)

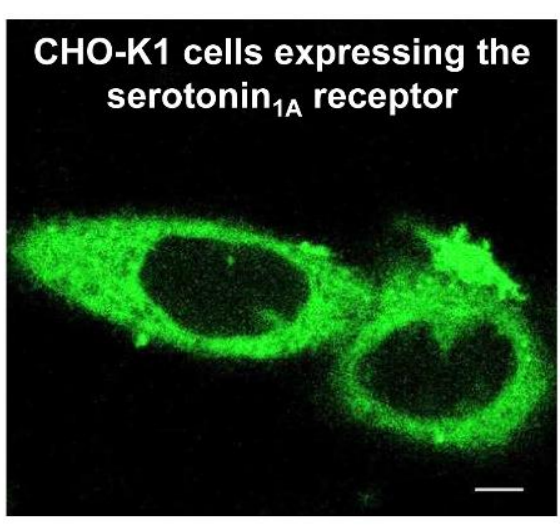

(b)

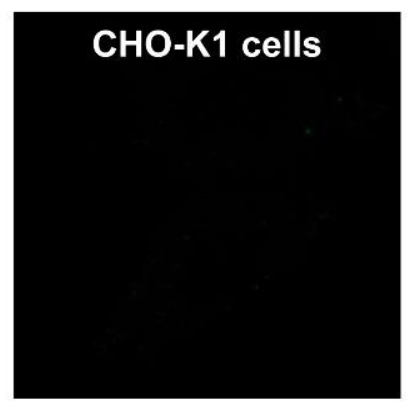

NBD

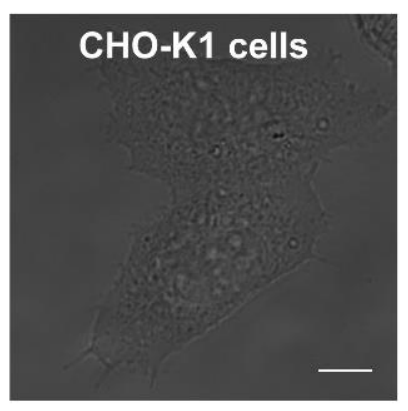

DIC

Figure 4. (a) Confocal microscopic images obtained by specific labeling of the serotonin ${ }_{1 \mathrm{~A}}$ receptor stably expressed in CHO-K1 cells with the NBD-labeled analog of serotonin (I). Cells were grown on Lab-Tek chambers and labeled with $7 \mu \mathrm{M}$ of analog I in HEPES-HANKS buffer, pH 7.2. NBD was excited using a $488 \mathrm{~nm}$ argon laser and emission was collected between 505-600 nm. Panel (b) shows background fluorescence of untransfected $\mathrm{CHO}-\mathrm{K} 1$ cells (lacking the serotonin ${ }_{1 \mathrm{~A}}$ receptor) labeled with $7 \mu \mathrm{M}$ of analog I under the same conditions as in panel (a). The right panel shows DIC image. Scale bars represent $10 \mu \mathrm{m}$. See Materials and Methods for other details. 
(a)
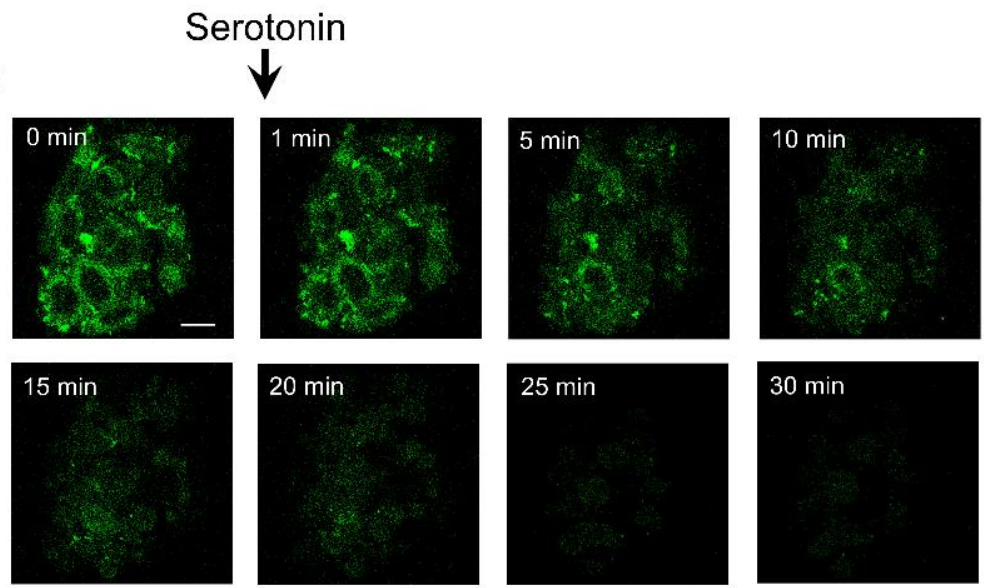

(b)
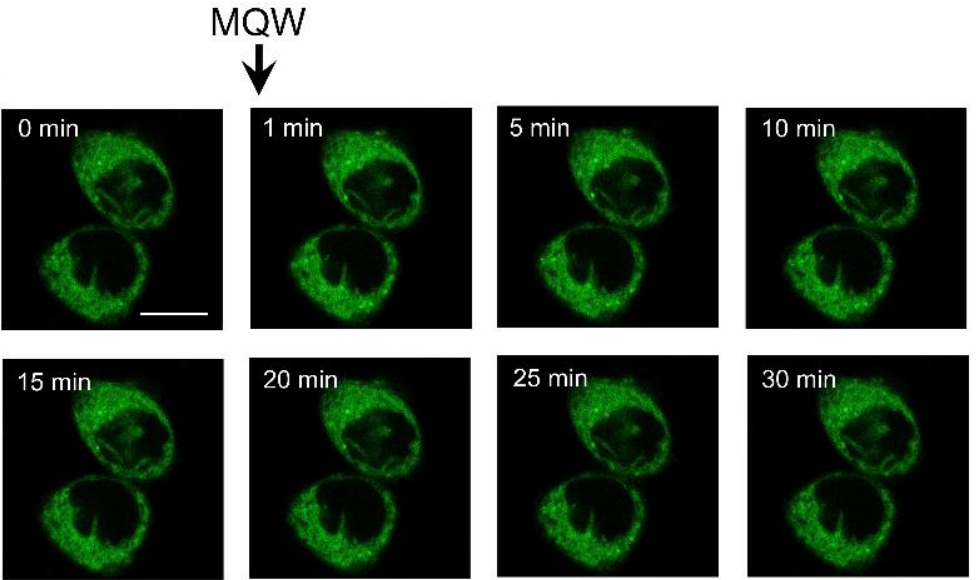

Figure 5. (a) Confocal microscopic images of the human serotonin ${ }_{1 \mathrm{~A}}$ receptor stably expressed in CHO-K1 cells labeled with the NBD-labeled analog of serotonin (I) and chased with unlabeled serotonin. Images represent mid-plane confocal sections of the same group of cells before and after addition of serotonin. Cells were initially labeled with $7 \mu \mathrm{M}$ of analog I in HEPES-HANKS buffer, pH 7.2 and subsequently serotonin (final concentration $7 \mathrm{mM}$ ) was added at 1 min time point (indicated by an arrow) from a concentrated aqueous stock solution. (b) Control experiment showing confocal microscopic images of the serotonin $_{1 \mathrm{~A}}$ receptor stably expressed in CHO-K1 cells labeled with the NBD-labeled analog of serotonin (I) and chased with same volume of Milli-Q water (MQW) as in panel (a). Images represent mid-plane confocal sections of the same group of cells before and after addition of MQW. Scale bars represent $10 \mu \mathrm{m}$. See Materials and Methods for other details.

We utilized a confocal microscopic set-up equipped with a multichannel spectral detector to construct pixel-by-pixel fluorescence emission spectra from confocal images of live cells (see Figure 6). For this, we used two excitation lines (488 and $514 \mathrm{~nm}$ ) of an argon laser and monitored the emission of NBD from serotonin $n_{1 \mathrm{~A}}$ receptor bound NBD-serotonin analog I between 493-622 $\mathrm{nm}$ (for excitation at $488 \mathrm{~nm}$ ) and 519-622 nm (for excitation at $514 \mathrm{~nm}$ ) with an interval of $\sim 4 \mathrm{~nm}$ (Figure 6). Figure 7a shows the representative fluorescence emission spectra of NBD-serotonin analog I bound to the human serotonin ${ }_{1 \mathrm{~A}}$ receptor in cells with increasing excitation wavelength Upon excitation at $488 \mathrm{~nm}$, NBDserotonin analog I in the serotonin ${ }_{1 \mathrm{~A}}$ receptor bound state displayed an emission maximum at $530 \mathrm{~nm}$ (Figure $7 \mathrm{a}, \mathrm{b})$. Interestingly, the emission maximum exhibited a shift toward longer wavelengths when the excitation wavelength was shifted to longer wavelength (Figure 7). Figure $7 \mathrm{~b}$ shows that when NBD was excited at $514 \mathrm{~nm}$, the maximum of fluorescence emission shifted to $559 \mathrm{~nm}$, corresponding to a REES of $29 \mathrm{~nm}$. Such a shift in the fluorescence emission maximum with a change in excitation wavelength suggests that the fluorescent NBD group in NBD-serotonin analog I is located in a motionally restricted environment. 


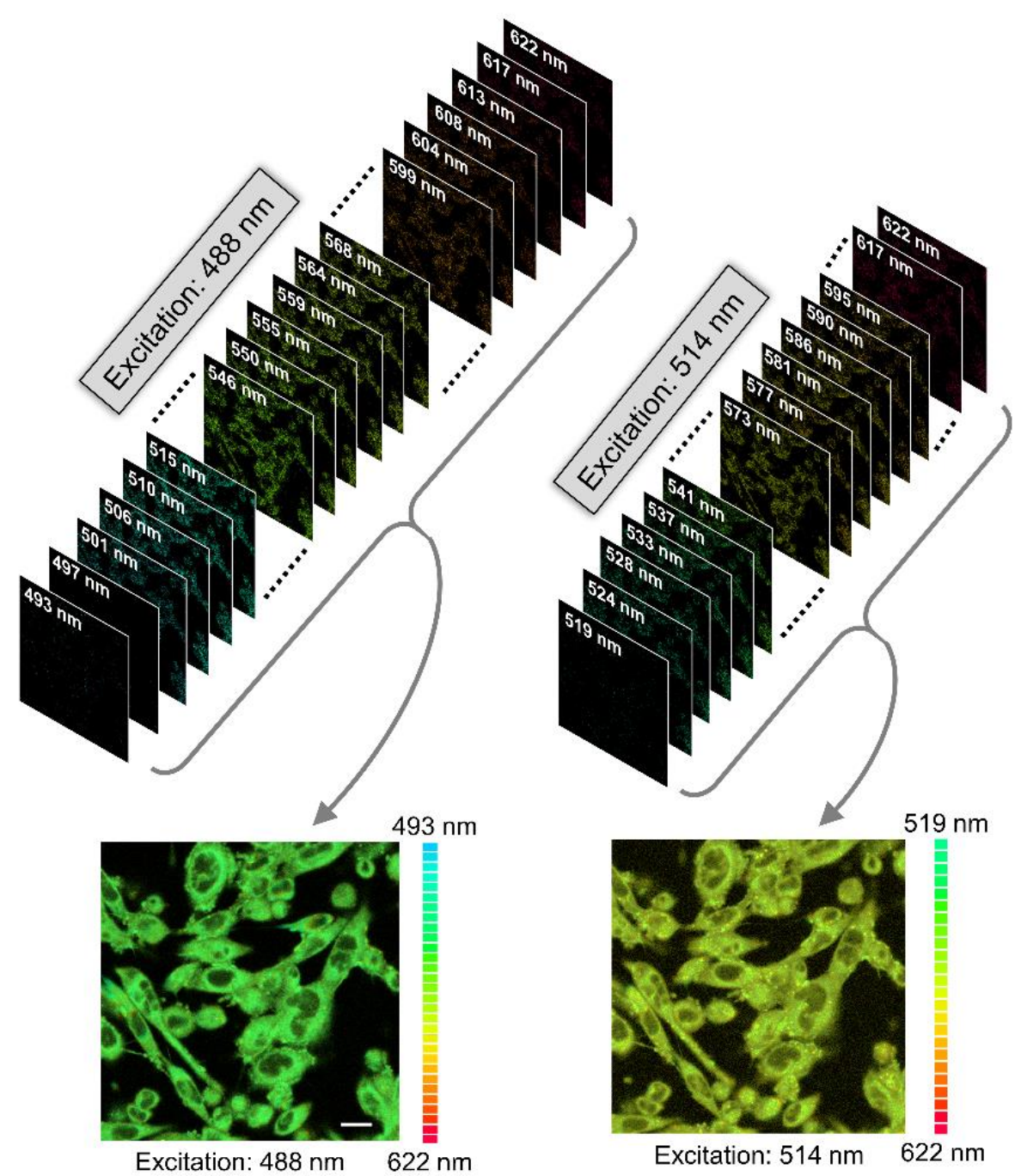

Figure 6. Spectral image stacks consisting of a collection of images showing serotonin ${ }_{1 \mathrm{~A}}$ receptor labeled using NBD-serotonin analog I, each of which measured at a specific wavelength (highlighted on top left corner of image) for two different excitation wavelengths. Unlike a typical confocal image, which is acquired over a wavelength range of the detector, a spectral image contains a collection of images of the same field captured at different wavelengths. As a result, spectral images provide a complete emission spectrum of the fluorophore at every pixel location. The corresponding overlaid image of the linearly unmixed spectral image stack is shown at the bottom. The individual images in the stack were colored according to the color-map showed beside the overlaid image. Note that the overall red-shifted emission of the NBD-serotonin analog I when excited at the red edge (514 $\mathrm{nm})$ indicates REES. The scale bar represents $10 \mu \mathrm{m}$. See Materials and Methods for other details. 
(a)
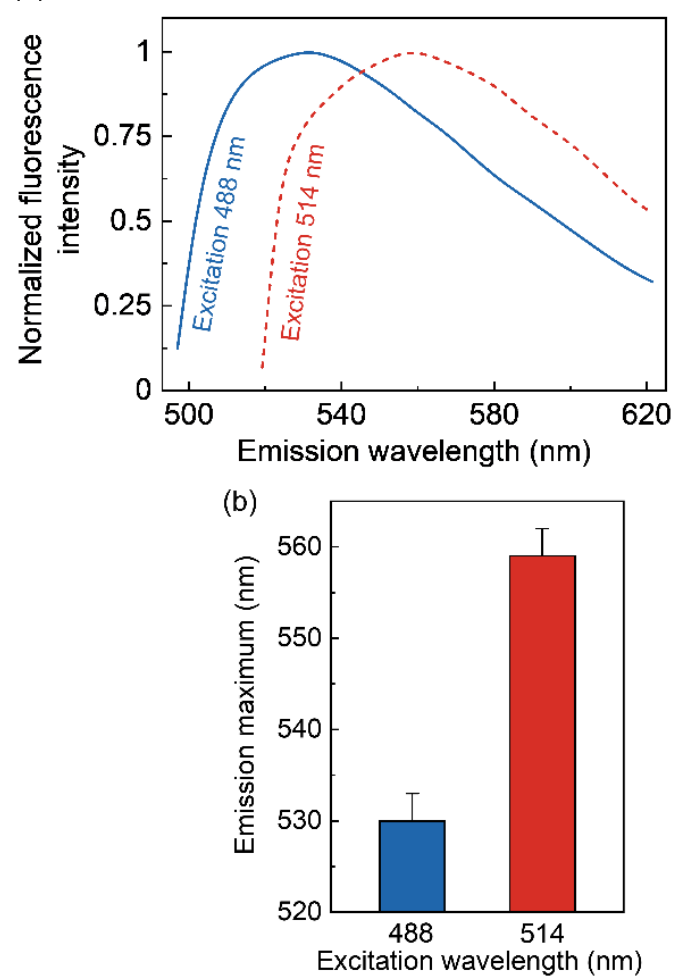

Figure 7. (a) Representative fluorescence emission spectra of NBD-serotonin analog I bound to the serotonin $_{1 \mathrm{~A}}$ receptor expressed in $\mathrm{CHO}-\mathrm{K} 1$ cells at different excitation wavelengths. The excitation wavelengths were 488 (-) and 514 (- - $\mathrm{nm}$. All spectra are intensity-normalized at the emission maximum. The concentration of NBD-serotonin analog I was $7 \mu \mathrm{M}$. A Zeiss LSM 880 inverted spectral imaging confocal microscope with a multichannel spectral detector was used to construct pixel-bypixel fluorescence emission spectra from the confocal images. (b) Effect of changing excitation wavelength on the wavelength of maximum emission for NBD-serotonin analog I. Data represent means \pm SE of at least 35 different fields from three independent experiments. See Materials and Methods for other details.

\section{Discussion}

Fluorescence-based approaches represent a convenient way to monitor and analyze biomolecular interactions at the molecular and cellular level. The advantages of employing fluorescence techniques include sensitivity, suitable time scale, minimal perturbation (non-invasive), and the dynamic nature of the information obtained. Due to significant improvements in instrumentation, the sensitivity of detection of fluorescence has immensely improved in the past few years. With the rapid development of confocal microscopy, the study of receptor biology using fluorescently labeled ligands has become popular [70,71]. Fluorescently labeled ligands have proven to be very useful in monitoring receptor binding sites, kinetics, regulation, clustering, dynamics, and trafficking [72-76]. Fluorescent ligands are often more attractive than radioligands, since affinity measurements can be performed by flow cytometry and receptor dynamics can be studied both at the cellular and the molecular level. In addition, structural information on receptor-ligand interaction can be obtained from fluorescence resonance energy transfer (FRET) experiments using appropriate donor and acceptor fluorescent labels [77]. Dynamic measurements (such as fluorescence recovery after photobleaching (FRAP)) can be conveniently used to monitor the lateral mobility (diffusion) of labeled receptors in tissue samples or in a single cell [78-82]. Importantly, fluorescence correlation spectroscopy (FCS), often using single receptor molecule, allows monitoring the interaction between the receptor and ligand [83] or lipid [84], and has been utilized for drug screening [85]. 
Serotonin exerts its diverse physiological actions by binding to specific receptors present in the plasma membrane $[4,14,16]$. For serotonin receptors in the GPCR family (except the serotonin ${ }_{3}$ receptor which is an ion channel), the ligand binding site lies within the transmembrane core of the receptor [52,55,86-89]. Interestingly, the conserved residues in GPCRs are predominantly located within the hydrophobic regions and not in the extraand intracellular loops that connect the transmembrane helices [90]. Sequence alignment of GPCRs revealed several conserved polar residues within the transmembrane segments, indicating that the hydrophilic residues in the transmembrane helices are the most probable sites of receptor-agonist interactions [90]. In the case of serotonin ${ }_{1 \mathrm{~A}}$ receptors, mutagenesis [50,62], molecular dynamics simulations [53,54], and cryo-EM structures [55] have revealed that the site for ligand binding is located within the transmembrane core of the receptor. Since the polarity of the microenvironment experienced by serotonin in such a position would be considerably lower than the bulk aqueous phase, we reasoned that a probe whose fluorescence is sensitive to this change in polarity upon binding would be helpful. In other words, the fluorescent probe labeled to serotonin should be solvatochromic to be able to 'sense' and faithfully report the microenvironment of the binding site. NBD is an ideal probe for this purpose, since its fluorescence is known to be highly sensitive to the polarity of the surrounding environment where it is placed [24,25]. This is primarily attributed to the large dipole moment change ( 3.9 D) of the NBD group upon excitation [38]. NBD exhibits extremely weak fluorescence in water, and when transferred to a hydrophobic medium, it fluoresces brightly in the visible range and shows a high sensitivity to its microenvironment $[24,25,33-38]$. In addition, the fluorescence lifetime of the NBD group is highly sensitive to the polarity of the surrounding environment [35,39-41].

NBD-labeled ligands have previously been used to label the nicotinic acetylcholine receptor [91], adenosine receptors [92], dopamine receptors [93], opioid receptors [94], and benzodiazepine receptors [95]. In the case of serotonin ${ }_{3}$ receptors, photolabile derivatives of serotonin have been developed for kinetic investigations [96]. In this work, we report the synthesis and application of NBD-labeled serotonin analogs. In these analogs, the NBD group is covalently attached to serotonin in such a manner that the binding properties do not exhibit very large change, as apparent from the apparent dissociation constants of the fluorescent analogs shown in Table 1. We showed that the fluorescent ligands competitively displace the serotonin ${ }_{1 \mathrm{~A}}$ receptor specific radiolabeled agonist $\left[{ }^{3} \mathrm{H}\right] 8-\mathrm{OH}-$ DPAT from the receptor, thereby demonstrating their binding specificity to the serotonin receptors. We further showed that serotonin ${ }_{1 \mathrm{~A}}$ receptors expressed in $\mathrm{CHO}-\mathrm{K} 1$ cells could be specifically labeled with one of the fluorescent ligands with minimal nonspecific labeling. Importantly, a useful feature of these fluorescent ligands is the environmental sensitivity of their fluorescence, as evident from our results (Table 2, Figures 3 and 7). This could prove to be helpful in exploring the physicochemical properties of the molecular environment (such as polarity) of the serotonin binding site in future studies.

\section{Materials and Methods}

\subsection{Materials}

Carbobenzyloxy-amino acids (alanine, glycine, and phenylalanine), EDTA, gentamicin sulfate, $\mathrm{HEPES}, \mathrm{MgCl}_{2}, \mathrm{MnCl}_{2}$, penicillin, polyethylenimine, serotonin hydrochloride, streptomycin sulfate, Tris, and trypsin were obtained from Sigma Chemical Co. (St. Louis, MO, USA). NBD chloride was purchased from Molecular Probes (Eugene, OR, USA). DMEM/F-12 (Ham's nutrient mixture, 1:1) and fetal calf serum (FCS) were obtained from Life Technologies Invitrogen/Life Technologies (Grand Island, NY, USA). $\left[{ }^{3} \mathrm{H}\right] 8-\mathrm{OH}-\mathrm{DPAT}$ $(127.2 \mathrm{Ci} / \mathrm{mmol})$ was obtained from DuPont New England Nuclear (Boston, MA, USA). GF/B glass microfiber filters were obtained from Whatman International (Kent, UK). The BCA reagent kit for protein estimation was obtained from Pierce (Rockford, IL, USA). Solvents used were of spectroscopic grade. The purity of the solvents was checked by the $E_{\mathrm{T}}(30)$ procedure (see below). The $E_{\mathrm{T}}(30)$ dye was a kind gift from Dr. Christian Reichardt (Philipps University, Marburg, Germany). All other chemicals used were of 
the highest available purity. Water was purified through a Millipore Milli-Q system and used throughout.

\subsection{Synthesis of NBD-Labeled Serotonin Analogs}

Synthesis of the NBD-labeled serotonin analogs were carried out as described in Supplementary Material (Section S1).

\subsection{Cell Culture}

CHO-K1 cells were maintained in DMEM/F-12 medium supplemented with $2.4 \mathrm{~g} / \mathrm{L}$ sodium bicarbonate, $10 \%(v / v) \mathrm{FCS}, 60 \mu \mathrm{g} / \mathrm{mL}$ penicillin, $50 \mu \mathrm{g} / \mathrm{mL}$ streptomycin and $50 \mu \mathrm{g} / \mathrm{mL}$ gentamycin sulfate (complete DMEM/F-12) in a humidified atmosphere with $5 \% \mathrm{CO}_{2}$ at $37^{\circ} \mathrm{C}$. CHO-K1 cells heterologously expressing the human serotonin ${ }_{1 \mathrm{~A}}$ receptor were maintained in complete DMEM/F-12 medium supplemented with $0.2 \mathrm{mg} / \mathrm{mL}$ G418 in a humidified atmosphere with $5 \% \mathrm{CO}_{2}$ at $37^{\circ} \mathrm{C}$. Cells were harvested after reaching $\sim 70-80 \%$ confluency ( $\sim 3$ days).

\subsection{Cell Membrane Preparation}

Confluent cells were washed once with phosphate buffered saline (PBS) and scraped off in ice-cold hypotonic buffer (10 mM Tris, 5 mM EDTA, pH 7.4) using a cell scraper. The cell suspension obtained was homogenized in a Bellco homogenizer (maximum speed for $2 \mathrm{~min}$ ) at $4{ }^{\circ} \mathrm{C}$. The homogenate obtained was centrifuged at $300,000 \times \mathrm{g}$ for $10 \mathrm{~min}$ in a Beckman ultracentrifuge. The supernatant was discarded and the pellet was resuspended

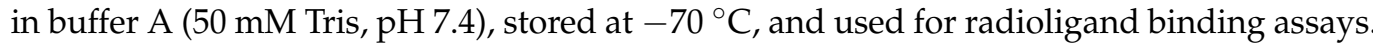
Protein concentration was determined using BCA reagent [97].

\subsection{Radioligand Binding Assay}

Radioligand binding assays in isolated membranes were carried out as described previously [64], with some modifications. See Supplementary Material (Section S2) for more details.

\subsection{Saturation Binding Assay}

Saturation binding assays were carried out as described previously [64]. Scatchard plots (i.e., plots of $R L^{*} / L^{*}$ vs. $R L^{*}$ where $L^{*}$ is the total ligand concentration) were analyzed. The dissociation constants $\left(\mathrm{K}_{\mathrm{d}}\right)$ were obtained from the negative inverse of the slopes, determined by linear regression analysis of the plots $(r=0.90-0.99)$. See Supplementary Material (Section S3) for more details.

\subsection{Competition Binding Assay}

Competition binding assays were carried out as described previously [64], with some modifications. The final concentrations of the competitive ligands in the assay tubes ranged from $10^{-12}$ to $10^{-4} \mathrm{M}$. The average of the $\mathrm{K}_{\mathrm{i}}$ values for the competitive ligands are shown in Table 1. See Supplementary Material (Section S4) for more details.

\subsection{Checking the Purity of Organic Solvents Using the $E_{T}(30)$ Dye}

The purity of organic solvents were checked using the $E_{\mathrm{T}}(30)$ dye as described previously [38]. The $E_{\mathrm{T}}(30)$ values obtained by us showed a maximum deviation of $<0.6 \%$ from the reported values for the solvents used in this study. See Supplementary Material (Section S5) for more details.

\subsection{Steady State Fluorescence Measurements}

Steady state fluorescence measurements were performed with a Hitachi F-4010 spectrofluorometer (Tokyo, Japan) using $1 \mathrm{~cm}$ path length quartz cuvettes. Excitation and emission slits with a bandpass of $5 \mathrm{~nm}$ were used for all measurements. Background intensities of samples in which fluorophores were omitted were negligible in most cases 
and were subtracted from each sample spectrum to cancel out any contribution due to the solvent Raman peak and other scattering artifacts. Data shown are representative of three independent measurements, and the reported emission maxima in Table 2 in each case were identical (or $\pm 1 \mathrm{~nm}$ of the values reported). The concentration of NBD-labeled serotonin analogs was calculated from their molar extinction coefficient of $20,000 \mathrm{M}^{-1} \mathrm{~cm}^{-1}$ at $460 \mathrm{~nm}$ [24]. The excitation wavelength used was $465 \mathrm{~nm}$ for all measurements. For fluorescence measurements, samples were prepared by drying NBD-labeled serotonin analogs (in methanol) under a stream of nitrogen while warming gently $\left(\sim 40^{\circ} \mathrm{C}\right)$. After further drying under a high vacuum for at least $12 \mathrm{~h}, 1.5 \mathrm{~mL}$ of solvent was added to the dried film and vortexed for $3 \mathrm{~min}$ to dissolve the NBD-labeled serotonin analogs in the solvent. The concentration of the fluorescent analogs was $8 \mu \mathrm{M}$ in all cases. The solvents used were tetrahydrofuran, acetone, isopropanol, ethanol, methanol, and dimethyl sulfoxide.

\subsection{Absorption Measurements}

Absorption spectra were recorded using a Hitachi U-2000 UV-visible absorption spectrophotometer (Tokyo, Japan) after appropriate baseline corrections. Quartz cuvettes with a path length of $1 \mathrm{~cm}$ were used.

\subsection{Fluorescent Labeling of CHO-K1 Cells Stably Expressing Serotonin ${ }_{1 A}$ Receptors}

$\mathrm{CHO}-\mathrm{K} 1$ cells stably expressing the human serotonin ${ }_{1 \mathrm{~A}}$ receptor were used for labeling with the NBD-labeled serotonin analog (analog I). Cells were plated on Lab-Tek chamber slides (Nunc, Denmark) and allowed to grow for 2 days. The stock solution of NBD-labeled serotonin analog I was prepared in methanol. The chamber slides were washed four times with HEPES-HANKS (10 mM, pH 7.2) buffer before labeling. Analog I (final concentration $7 \mu \mathrm{M}$ ) in HEPES-HANKS buffer was then added to the chamber slides and incubated at $37^{\circ} \mathrm{C}$ for $30 \mathrm{~min}$ (the final methanol concentration was $0.2 \%(v / v)$ ). The chamber slides were then washed three times with HEPES-HANKS buffer to remove unbound analog I, and confocal imaging was carried out at room temperature $\left(\sim 23^{\circ} \mathrm{C}\right)$ in HEPES-HANKS buffer. In a control experiment, untransfected $\mathrm{CHO}-\mathrm{K} 1$ cells (without expressing the $\operatorname{serotonin}_{1 \mathrm{~A}}$ receptor) were labeled with analog I $(7 \mu \mathrm{M})$ in HEPES-HANKS buffer for $30 \mathrm{~min}$ at $37^{\circ} \mathrm{C}$. In another experiment, $\mathrm{CHO}-\mathrm{K} 1$ cells stably expressing the human serotonin ${ }_{1 \mathrm{~A}}$ receptor were first labeled with analog I and subsequently incubated with $7 \mathrm{mM}$ unlabeled serotonin for various time points.

\subsection{Fluorescence Microscopy and Imaging}

Images were acquired using an inverted Zeiss LSM 880 confocal microscope (Jena, Germany) with a $63 \times / 1.4$ NA oil immersion objective under one airy condition. NBD was excited using the $488 \mathrm{~nm}$ line of an Argon laser, and emission was collected from 500-600 nm. For time series experiments, images were collected at an interval of $1 \mathrm{~min}$ for a total duration of $30 \mathrm{~min}$. Image analyses were performed using ImageJ (NIH, Bethesda, MD, USA). Spectral imaging was carried out using a 34 channel GaASP spectral detector with a spectral resolution of $\sim 4 \mathrm{~nm}$. Images were collected using 488 and $514 \mathrm{~nm}$ lines of an Argon laser and spectral images were collected between 493-622 nm and 519-622 nm, respectively. Spectral unmixing and processing of the obtained images were performed using the ZEN imaging software (Zeiss, Jena, Germany).

\section{Conclusions}

Taken together, the novel NBD-labeled serotonin analogs represent a useful class of probes and offer an attractive fluorescent approach to study serotonin receptors and their interactions with specific ligands and lipids and their cellular localization and regulation as well as to monitor the mobility and dynamics of serotonin receptors in normal and diseased states. Considering the multiple roles of serotonin receptors both in the central and peripheral nervous systems, these fluorescent ligands should prove to be useful in future studies involving serotonergic systems. 
Supplementary Materials: Method S1: Synthesis of NBD-labeled serotonin analogs, Method S2: Radioligand binding assay, Method S3: Saturation binding assay, Method S4: Competition binding assay, Method S5, Checking the purity of organic solvents using the ET(30) dye, Figure S1: A threestep protocol followed for the synthesis of NBD-labeled serotonin analogs I-III, Figure S2: Mass spectra of NBD-Ala-serotonin analog I, Figure S3: Absorption spectra of NBD-labeled analogs of serotonin (I) in solvents of varying polarity

Author Contributions: P.S., K.G.H., S.S.R. and S.D. performed experiments. P.S. and T.K.C. analyzed data and prepared figures. P.S., T.K.C. and A.C. designed experiments. P.S. and A.C. wrote the manuscript. A.C. edited the manuscript, organized access to research facilities and funding, and provided overall supervision and mentoring. All authors have read and agreed to the published version of the manuscript.

Funding: This work was supported by core support from CSIR-Centre for Cellular and Molecular Biology to A.C.

Institutional Review Board Statement: Not applicable.

Informed Consent Statement: Not applicable.

Data Availability Statement: The data presented in this study are available on request from the corresponding author.

Acknowledgments: P.S. thanks the CSIR for the award of a Shyama Prasad Mukherjee Fellowship. We thank B. Raman for help with structural characterization. We thank the members of the Chattopadhyay laboratory for critically reading the manuscript and for their comments.

Conflicts of Interest: The authors declare no conflict of interest.

\begin{abstract}
Abbreviations
BCA, bicinchoninic acid; Cbz, carbobenzyloxy; DIPEA, N,N-diisopropylethylamine; DMEM, Dulbecco's modified Eagle's medium; DMF, N,N-Dimethylformamide; EDTA, ethylenediaminetetraacetic acid; EDCI, 1-ethyl-3-(3-dimethylaminopropyl)carbodiimide hydrochloride; ET(30), 2,6-diphenyl-4(2,4,6-triphenyl-N-pyridinio)phenoxide; HEPES, 4-(2-hydroxyethyl)-1-piperazine ethanesulfonic acid; HOBt, 1-hydroxybenzotriazole; 8-OH-DPAT, 8-hydroxy-2(di-N-propylamino)tetralin; NBD, 7-nitrobenz2-oxa-1,3-diazol-4-yl; REES, red edge excitation shift; Tris, tris-(hydroxymethyl)aminomethane.
\end{abstract}

\title{
References
}

1. Whitaker-Azmitia, P.M. The discovery of serotonin and its role in neuroscience. Neuropsychopharmacology 1999, 21, 2S-8S. [CrossRef]

2. Jacobs, B.L.; Azmitia, E.C. Structure and function of the brain serotonin system. Physiol. Rev. 1992, 72, 165-229. [CrossRef]

3. Hen, R. Of mice and flies: Commonalities among 5-HT receptors. Trends Pharmacol. Sci. 1992, 13, 160-165. [CrossRef]

4. Nichols, D.E.; Nichols, C.D. Serotonin receptors. Chem. Rev. 2008, 108, 1614-1641. [CrossRef] [PubMed]

5. Lin, S.-H.; Lee, L.-T.; Yang, Y.K. Serotonin and mental disorders: A concise review on molecular neuroimaging evidence. Clin. Psychopharmacol. Neurosci. 2014, 12, 196-202. [CrossRef] [PubMed]

6. Cowen, P.J.; Browning, M. What has serotonin to do with depression? World Psychiatry 2015, 14, 158-160. [CrossRef] [PubMed]

7. Stiedl, O.; Pappa, E.; Konradsson-Geuken, A.; Ögren, S.O. The role of the serotonin receptor subtypes $5-\mathrm{HT}_{1 \mathrm{~A}}$ and 5-HT 7 and its interaction in emotional learning and memory. Front. Pharmacol. 2015, 6, 162. [CrossRef] [PubMed]

8. Yohn, C.N.; Gergues, M.M.; Samuels, B.A. The role of 5-HT receptors in depression. Mol. Brain 2017, 10, 28. [CrossRef] [PubMed]

9. Carhart-Harris, R.L.; Nutt, D.J. Serotonin and brain function: A tale of two receptors. J. Psychopharm. 2017, 31, 1091-1120. [CrossRef] [PubMed]

10. Underwood, M.D.; Kassir, S.A.; Bakalian, M.J.; Galfalvy, H.; Dwork, A.J.; Mann, J.J.; Arango, V. Serotonin receptors and suicide, major depression, alcohol use disorder and reported early life adversity. Transl. Psychiatry 2018, 8, 279. [CrossRef]

11. Heisler, L.K.; Chu, H.-M.; Brennan, T.J.; Danao, J.A.; Bajwa, P.; Parsons, L.H.; Tecott, L.H. Elevated anxiety and antidepressant-like responses in serotonin 5- $\mathrm{HT}_{1 \mathrm{~A}}$ receptor mutant mice. Proc. Natl. Acad. Sci. USA 1998, 95, 15049-15054. [CrossRef]

12. Berger, M.; Gray, J.A.; Roth, B.L. The expanded biology of serotonin. Ann. Rev. Med. 2009, 60, 355-366. [CrossRef]

13. McCorvy, J.D.; Roth, B.L. Structure and function of serotonin G protein-coupled receptors. Pharmacol. Ther. 2015, 150, 129-142. [CrossRef] [PubMed]

14. Peroutka, S.J. 5-Hydroxytryptamine receptors. J. Neurochem. 1993, 60, 408-416. [CrossRef] [PubMed] 
15. Sarkar, P.; Kumar, G.A.; Pal, S.; Chattopadhyay, A. Biophysics of Serotonin and the Serotonin ${ }_{1 a}$ Receptor: Fluorescence and Dynamics. In Serotonin: The Mediator that Spans Evolution; Pilowsky, P., Ed.; Elsevier: Amsterdam, The Netherlands, 2018; pp. 3-22.

16. Sarkar, P.; Mozumder, S.; Bej, A.; Mukherjee, S.; Sengupta, J.; Chattopadhyay, A. Structure, dynamics and lipid interactions of serotonin receptors: Excitements and challenges. Biophys. Rev. 2021, 13, 101-122. [CrossRef] [PubMed]

17. Barnes, N.M.; Ahern, G.P.; Becamel, C.; Bockaert, J.; Camilleri, M.; Chaumont-Dubel, S.; Claeysen, S.; Cunningham, K.A.; Fone, K.C.; Gershon, M. International Union of Basic and Clinical Pharmacology. CX. Classification of receptors for 5hydroxytryptamine; pharmacology and function. Pharmacol. Rev. 2021, 73, 310-520. [CrossRef] [PubMed]

18. Westkaemper, R.B.; Roth, B.L. Structure and Function Reveal Insights in the Pharmacology of 5ht Receptor Subtype. In The Serotonin Receptors; Roth, B.L., Ed.; Humana Press: Totowa, NJ, USA, 2006; pp. 39-58.

19. Pucadyil, T.J.; Kalipatnapu, S.; Chattopadhyay, A. The serotonin ${ }_{1 \mathrm{~A}}$ receptor: A representative member of the serotonin receptor family. Cell. Mol. Neurobiol. 2005, 25, 553-580. [CrossRef] [PubMed]

20. Lacivita, E.; Leopoldo, M.; Berardi, F.; Perrone, R. 5-HT 1 A receptor, an old target for new therapeutic agents. Curr. Top. Med. Chem. 2008, 8, 1024-1034. [CrossRef] [PubMed]

21. Fiorino, F.; Severino, B.; Magli, E.; Ciano, A.; Caliendo, G.; Santagada, V.; Frecentese, F.; Perissutti, E. 5-HT 1 A receptor: An old target as a new attractive tool in drug discovery from CNS to cancer. J. Med. Chem. 2014, 57, 4407-4426. [CrossRef]

22. Chattopadhyay, A.; Rukmini, R.; Mukherjee, S. Photophysics of a neurotransmitter: Ionization and spectroscopic properties of serotonin. Biophys. J. 1996, 71, 1952-1960. [CrossRef]

23. Dunn, K.; Maxfield, F.R. Ratio imaging instrumentation. Methods Cell Biol. 2003, 56, 217-236.

24. Chattopadhyay, A. Chemistry and biology of N-(7-nitrobenz-2-oxa-1,3-diazol-4-yl)-labeled lipids: Fluorescent probes of biological and model membranes. Chem. Phys. Lipids 1990, 53, 1-15. [CrossRef]

25. Haldar, S.; Chattopadhyay, A. Application of NBD-Labeled Lipids in Membrane and Cell Biology. In Springer Series on Fluorescence; Mély, Y., Duportail, G., Eds.; Springer: Heidelberg, Germany, 2013; Volume 13, pp. 37-50.

26. Kobayashi, T.; Pagano, R.E. ATP-dependent fusion of liposomes with the Golgi apparatus of perforated cells. Cell 1988, 55, 797-805. [CrossRef]

27. Crowley, K.S.; Reinhart, G.D.; Johnson, A.E. The signal sequence moves through a ribosomal tunnel into a noncytoplasmic aqueous environment at the ER membrane early in translocation. Cell 1993, 73, 1101-1115. [CrossRef]

28. Mazeres, S.; Schram, V.; Tocanne, J.-F.; Lopez, A. 7-Nitrobenz-2-oxa-1,3-diazole-4-yl-labeled phospholipids in lipid membranes: Differences in fluorescence behavior. Biophys. J. 1996, 71, 327-335. [CrossRef]

29. Liao, S.; Lin, J.; Do, H.; Johnson, A.E. Both lumenal and cytosolic gating of the aqueous ER translocon pore are regulated from inside the ribosome during membrane protein integration. Cell 1997, 90, 31-41. [CrossRef]

30. Chattopadhyay, A.; Mukherjee, S. Red edge excitation shift of a deeply embedded membrane probe: Implications in water penetration in the bilayer. J. Phys. Chem. B 1999, 103, 8180-8185. [CrossRef]

31. Pucadyil, T.J.; Mukherjee, S.; Chattopadhyay, A. Organization and dynamics of NBD-labeled lipids in membranes analyzed by fluorescence recovery after photobleaching. J. Phys. Chem. B 2007, 111, 1975-1983. [CrossRef]

32. Lajevardipour, A.; Chon, J.W.M.; Chattopadhyay, A.; Clayton, A.H.A. Imaging cellular dynamics with spectral relaxation imaging microscopy: Distinct spectral dynamics in Golgi membranes of living cells. Sci. Rep. 2016, 6, 37038. [CrossRef]

33. Chattopadhyay, A.; London, E. Spectroscopic and ionization properties of N-(7-nitrobenz-2-oxa-1,3-diazol-4-yl)-labeled lipids in model membranes. Biochim. Biophys. Acta 1988, 938, 24-34. [CrossRef]

34. Rajarathnam, K.; Hochman, J.; Schindler, M.; Ferguson-Miller, S. Synthesis, location, and lateral mobility of fluorescently labeled ubiquinone 10 in mitochondrial and artificial membranes. Biochemistry 1989, 28, 3168-3176. [CrossRef] [PubMed]

35. Lin, S.; Struve, W.S. Time-resolved fluorescence of nitrobenzoxadiazole-aminohexanoic acid: Effect of intermolecular hydrogenbonding on non-radiative decay. Photochem. Photobiol. 1991, 54, 361-365. [CrossRef]

36. Chattopadhyay, A.; Mukherjee, S. Fluorophore environments in membrane-bound probes: A red edge excitation shift study. Biochemistry 1993, 32, 3804-3811. [CrossRef]

37. Fery-Forgues, S.; Fayet, J.-P.; Lopez, A. Drastic changes in the fluorescence properties of NBD probes with the polarity of the medium: Involvement of a TICT state? J. Photochem. Photobiol. A 1993, 70, 229-243. [CrossRef]

38. Mukherjee, S.; Chattopadhyay, A.; Samanta, A.; Soujanya, T. Dipole moment change of NBD group upon excitation studied using solvatochromic and quantum chemical approaches: Implications in membrane research. J. Phys. Chem. 1994, 98, 2809-2812. [CrossRef]

39. Rawat, S.S.; Chattopadhyay, A. Structural transition in the micellar assembly: A fluorescence study. J. Fluoresc. 1999, 9, 233-244. [CrossRef]

40. Chattopadhyay, A.; Mukherjee, S.; Raghuraman, H. Reverse micellar organization and dynamics: A wavelength-selective fluorescence approach. J. Phys. Chem. B 2002, 106, 13002-13009. [CrossRef]

41. Raghuraman, H.; Chattopadhyay, A. Orientation and dynamics of melittin in membranes of varying composition utilizing NBD fluorescence. Biophys. J. 2007, 92, 1271-1283. [CrossRef]

42. Pagano, R.E.; Sleight, R.G. Defining lipid transport pathways in animal cells. Science 1985, 229, 1051-1057. [CrossRef]

43. Van Meer, G.; Stelzer, E.H.K.; Wijnaendts-van-Resandt, R.W.; Simons, K. Sorting of sphingolipids in epithelial (Madin-Darby canine kidney) cells. J. Cell Biol. 1987, 105, 1623-1635. [CrossRef] [PubMed] 
44. Koval, M.; Pagano, R.E. Sorting of an internalized plasma membrane lipid between recycling and degradative pathways in normal and Niemann-Pick, type A fibroblasts. J. Cell Biol. 1990, 111, 429-442. [CrossRef]

45. Sleight, R.G. Fluorescent glycerolipid probes. Synthesis and use for examining intracellular lipid trafficking. Methods Mol. Biol. 1994, 27, 143-160.

46. Huijbregts, R.P.H.; Kroon, A.I.P.M.D.; Kruijff, B.D. Rapid transmembrane movement of $\mathrm{C}_{6}$-NBD-labeled phospholipids across the inner membrane of Escherichia coli. Biochim. Biophys. Acta 1996, 1280, 41-50. [CrossRef]

47. Grant, A.M.; Hanson, P.K.; Malone, L.; Nichols, J.W. NBD-labeled phosphatidylcholine and phosphatidylethanolamine are internalized by transbilayer transport across the yeast plasma membrane. Traffic 2001, 2, 37-50. [CrossRef]

48. Ramirez, D.M.C.; Ogilvie, W.W.; Johnston, L.J. NBD-cholesterol probes to track cholesterol distribution in model membranes. Biochim. Biophys. Acta 2010, 1798, 558-568. [CrossRef] [PubMed]

49. Elvington, S.M.; Bu, F.; Nichols, J.W. Fluorescent, acyl chain-labeled phosphatidylcholine analogs reveal novel transport pathways across the plasma membrane of yeast. J. Biol. Chem. 2005, 280, 40957-40964. [CrossRef] [PubMed]

50. Ho, B.Y.; Karschin, A.; Branchek, T.; Davidson, N.; Lester, H.A. The role of conserved aspartate and serine residues in ligand binding and in function of the 5-HT $\mathrm{H}_{1 \mathrm{~A}}$ receptor: A site-directed mutation study. FEBS Lett. 1992, 312, 259-262. [CrossRef]

51. Bremner, D.H.; Ringan, N.S.; Wishart, G. Modeling of the agonist binding site of serotonin human 5-HT $1 \mathrm{~A}, 5-\mathrm{T}_{1 \mathrm{D} \alpha}$ and $5-\mathrm{HT}_{1 \mathrm{D} \beta}$ receptors. Eur. J. Med. Chem. 1997, 32, 59-69. [CrossRef]

52. Paila, Y.D.; Tiwari, S.; Sengupta, D.; Chattopadhyay, A. Molecular modeling of the human serotonin 1 A receptor: Role of membrane cholesterol in ligand binding of the receptor. Mol. Biosyst. 2011, 7, 224-234. [CrossRef]

53. Sylte, I.; Edvardsen, Ø.; Dahl, S.G. Molecular modelling of UH-301 and 5-HT 1a receptor interactions. Protein Eng. 1996, 9, 149-160. [CrossRef] [PubMed]

54. Kuipers, W.; Link, R.; Standaar, P.J.; Stoit, A.R.; Van Wijngaarden, I.; Leurs, R.; Ijzerman, A.P. Study of the interaction between aryloxypropanolamines and Asn386 in helix VII of the human 5-hydroxytryptamine ${ }_{1 \mathrm{~A}}$ receptor. Mol. Pharmacol. 1997, 51, 889-896. [CrossRef] [PubMed]

55. Xu, P.; Huang, S.; Zhang, H.; Huang, S.; Zhang, H.; Mao, C.; Zhou, X.E.; Cheng, X.; Simon, I.A.; Shen, D.-D.; et al. Structural insights into the lipid and ligand regulation of serotonin receptors. Nature 2021, 592, 469-473. [CrossRef] [PubMed]

56. Hogendorf, A.S.; Hogendorf, A.; Popiołek-Barczyk, K.; Ciechanowska, A.; Mika, J.; Satała, G.; Walczak, M.; Latacz, G.; Handzlik, J.; Kieć-Kononowicz, K.; et al. Fluorinated indole-imidazole conjugates: Selective orally bioavailable 5-HT 7 receptor low-basicity agonists, potential neuropathic painkillers. Eur. J. Med. Chem. 2019, 170, 261-275. [CrossRef] [PubMed]

57. Podlewska, S.; Bugno, R.; Lacivita, E.; Leopoldo, M.; Bojarski, A.J.; Handzlik, J. Low basicity as a characteristic for atypical ligands of serotonin receptor 5-HT 2 . Int. J. Mol. Sci. 2021, 22, 1035. [CrossRef]

58. Gozlan, H.; Mestikawy, S.E.; Pichat, L.; Glowinski, J.; Hamon, M. Identification of presynaptic serotonin autoreceptors using a new ligand: ${ }^{3}$ H-PAT. Nature 1983, 305, 140-142. [CrossRef]

59. Hall, M.D.; Mestikawy, S.E.; Emerit, M.B.; Pichat, L.; Hamon, M.; Gozlan, H. $\left[{ }^{3}\right.$ H] 8 -hydroxy-2-(di- $n$-propylamino)tetralin binding to pre- and postsynatptic 5-hydroxytryptamine sites in various regions of the rat brain. J. Neurochem. 1985, 44, 1685-1696. [CrossRef]

60. Cheng, Y.; Prusoff, W.H. Relationship between the inhibition constant $\left(\mathrm{K}_{\mathrm{i}}\right)$ and the concentration of inhibitor which causes 50 per cent inhibition $\left(\mathrm{IC}_{50}\right)$ of an enzymatic reaction. Biochem. Pharmacol. 1973, 22, 3099-3108.

61. Hulme, E.C. Receptor-Effector Coupling: A Practical Approach; IRL Press: New York, NY, USA, 1990.

62. Chanda, P.K.; Minchin, M.C.; Davis, A.R.; Greenberg, L.; Reilly, Y.; McGregor, W.H.; Bhat, R.; Lubeck, M.D.; Mizutani, S.; Hung, P.P. Identification of residues important for ligand binding to the human 5-hydroxytryptamine ${ }_{1 \mathrm{~A}}$ serotonin receptor. Mol. Pharmacol. 1993, 43, 516-520.

63. Lide, D.R. CRC Handbook of Chemistry and Physics; CRC Press: Boca Raton, FL, USA, 1992.

64. Kalipatnapu, S.; Pucadyil, T.J.; Harikumar, K.G.; Chattopadhyay, A. Ligand binding characteristics of the human serotonin 1 A receptor heterologously expressed in CHO cells. Biosci. Rep. 2004, 24, 101-115. [CrossRef]

65. Haldar, S.; Chaudhuri, A.; Chattopadhyay, A. Organization and dynamics of membrane probes and proteins utilizing the red edge excitation shift. J. Phys. Chem. B 2011, 115, 5693-5706. [CrossRef]

66. Chattopadhyay, A.; Haldar, S. Dynamic insight into protein structure utilizing red edge excitation shift. Acc. Chem. Res. 2014, 47, 12-19. [CrossRef] [PubMed]

67. Mukherjee, S.; Chattopadhyay, A. Wavelength-selective fluorescence as a novel tool to study organization and dynamics in complex biological systems. J. Fluoresc. 1995, 5, 237-246. [CrossRef] [PubMed]

68. Demchenko, A.P. Site-selective red-edge effects. Methods Enzymol. 2008, 450, 59-78.

69. Brahma, R.; Raghuraman, H. Novel insights in linking solvent relaxation dynamics and protein conformations utilizing red edge excitation shift approach. Emerg. Top. Life Sci. 2021, 5, 89-101. [PubMed]

70. Leopoldo, M.; Lacivita, E.; Berardi, F.; Perrone, R. Developments in fluorescent probes for receptor research. Drug Discov. Today 2009, 14, 706-712. [CrossRef]

71. Stoddart, L.A.; Kilpatrick, L.E.; Briddon, S.J.; Hill, S.J. Probing the pharmacology of G protein-coupled receptors with fluorescent ligands. Neuropharmacology 2015, 98, 48-57. [CrossRef]

72. McGrath, J.C.; Arribas, S.; Daly, C.J. Fluorescent ligands for the study of receptors. Trends Pharmacol. Sci. 1996, 17, 393-399. [CrossRef] 
73. Lacivita, E.; Leopoldo, M.; Masotti, A.C.; Contino, M.; Berardi, F.; Perrone, R.; Ganguly, S.; Jafurulla, M.; Chattopadhyay, A. Synthesis and characterization of environment-sensitive fluorescent ligands for human $5-\mathrm{HT}_{1 \mathrm{~A}}$ receptors with 1-arylpiperazine structure. J. Med. Chem. 2009, 52, 7892-7896. [CrossRef]

74. Lacivita, E.; Masotti, A.C.; Jafurulla, M.; Saxena, R.; Rangaraj, N.; Chattopadhyay, A.; Colabufo, N.A.; Berardi, F.; Perrone, R.; Leopoldo, M. Identification of a red-emitting fluorescent ligand suitable for in vitro visualization of human serotonin 5 - $\mathrm{HT}_{1 \mathrm{~A}}$ receptors. Bioorg. Med. Chem. Lett. 2010, 20, 6628-6632. [CrossRef]

75. Sridharan, R.; Zuber, J.; Connelly, S.M.; Mathew, E.; Dumont, M.E. Fluorescent approaches for understanding interactions of ligands with $G$ protein coupled receptors. Biochim. Biophys. Acta 2014, 1838, 15-33. [CrossRef]

76. Soave, M.; Briddon, S.J.; Hill, S.J.; Stoddart, L.A. Fluorescent ligands: Bringing light to emerging GPCR paradigms. Br. J. Pharmacol. 2020, 177, 978-991. [CrossRef] [PubMed]

77. Rocheville, M.; Lange, D.C.; Kumar, U.; Patel, S.C.; Patel, R.C.; Patel, Y.C. Receptors for dopamine and somatostatin: Formation of hetero-oligomers with enhanced functional activity. Science 2000, 288, 154-157. [CrossRef]

78. Roettger, B.F.; Pinon, D.I.; Burghardt, T.P.; Miller, L.J. Regulation of lateral mobility and cellular trafficking of the CCK receptor by a partial agonist. Am. J. Physiol. 1999, 276, C539-C547. [CrossRef] [PubMed]

79. Pucadyil, T.J.; Kalipatnapu, S.; Harikumar, K.G.; Rangaraj, N.; Karnik, S.S.; Chattopadhyay, A. G-protein-dependent cell surface dynamics of the human serotonin ${ }_{1 \mathrm{~A}}$ receptor tagged to yellow fluorescent protein. Biochemistry 2004, 43, 15852-15862. [CrossRef] [PubMed]

80. Pucadyil, T.J.; Chattopadhyay, A. Cholesterol depletion induces dynamic confinement of the G-protein coupled serotonin $1 \mathrm{~A}$ receptor in the plasma membrane of living cells. Biochim. Biophys. Acta 2007, 1768, 655-668. [CrossRef] [PubMed]

81. Chattopadhyay, A.; Jafurulla, M. Novel insights in membrane biology utilizing fluorescence recovery after photobleaching. Adv. Exp. Med. Biol. 2015, 842, 27-40. [PubMed]

82. Sarkar, P.; Chattopadhyay, A. Exploring Membrane Lipid and Protein Diffusion by FRAP. In Analysis of Membrane Lipids; Prasad, R., Singh, A., Eds.; Springer: Berlin, Germany, 2020; pp. 119-141.

83. Sako, Y.; Minoghchi, S.; Yanagida, T. Single-molecule imaging of EGFR signalling on the surface of living cells. Nat. Cell Biol. 2000, 2, 168-172. [CrossRef]

84. Ganguly, S.; Chattopadhyay, A. Cholesterol depletion mimics the effect of cytoskeletal destabilization on membrane dynamics of the serotonin ${ }_{1 \mathrm{~A}}$ receptor: A zFCS study. Biophys. J. 2010, 99, 1397-1407. [CrossRef]

85. Auer, M.; Moore, K.J.; Meyer-Almes, F.J.; Guenther, R.; Pope, A.J.; Stoeckli, K.A. Fluorescence correlation spectroscopy: Lead discovery by miniaturized HTS. Drug Discov. Today 1998, 3, 457-465. [CrossRef]

86. Wacker, D.; Wang, C.; Katritch, V.; Han, G.W.; Huang, X.-P.; Vardy, E.; McCorvy, J.D.; Jiang, Y.; Chu, M.; Siu, F.Y.; et al. Structural features for functional selectivity at serotonin receptors. Science 2013, 340, 615-619. [CrossRef]

87. Wang, C.; Jiang, Y.; Ma, J.; Wu, H.; Wacker, D.; Katritch, V.; Han, G.W.; Liu, W.; Huang, X.-P.; Vardy, E.; et al. Structural basis for molecular recognition at serotonin receptors. Science 2013, 340, 610-614. [CrossRef] [PubMed]

88. Peng, Y.; McCorvy, J.D.; Harpsøe, K.; Lansu, K.; Yuan, S.; Popov, P.; Qu, L.; Pu, M.; Che, T.; Nikolajsen, L.F.; et al. 5-HT2C receptor structures reveal the structural basis of GPCR polypharmacology. Cell 2018, 172, 719-730.e14. [CrossRef] [PubMed]

89. Kim, K.; Che, T.; Panova, O.; DiBerto, J.F.; Lyu, J.; Krumm, B.E.; Wacker, D.; Robertson, M.J.; Seven, A.B.; Nichols, D.E.; et al. Structure of a hallucinogen-activated Gq-coupled 5-HT $2 \mathrm{~A}$ serotonin receptor. Cell 2020, 182, 1574-1588. [CrossRef] [PubMed]

90. Surgand, J.-S.; Rodrigo, J.; Kellenberger, E.; Rognan, D. A chemogenomic analysis of the transmembrane binding cavity of human G-protein-coupled receptors. Proteins 2006, 62, 509-538. [CrossRef] [PubMed]

91. Jürss, R.; Prinz, H.; Maelicke, A. NBD-5-acylcholine: Fluorescent analog of acetylcholine and agonist at the neuromuscular junction. Proc. Natl. Acad. Sci. USA 1979, 76, 1064-1068. [CrossRef] [PubMed]

92. Jacobson, K.A.; Ukena, D.; Padgett, W.; Kirk, K.L.; Daly, J.W. Molecular probes for extracellular adenosine receptors. Biochem. Pharmacol. 1987, 36, 1697-1707. [CrossRef]

93. Bakthavachalam, V.; Baindur, N.; Madras, B.K.; Neumeyer, J.L. Fluorescent probes for dopamine receptors: Synthesis and characterization of fluorescein and 7-nitrobenz-2-oxa-1,3-diazol-4-yl conjugates of D-1 and D-2 receptor ligands. J. Med. Chem. 1991, 34, 3235-3241. [CrossRef]

94. Archer, S.; Medzihradsky, F.; Seyed-Mozaffari, A.; Emmerson, P.J. Synthesis and characterization of 7-nitrobenzo-2-oxa-1,3-diazole (NBD)-labeled fluorescent opioids. Biochem. Pharmacol. 1992, 43, 301-306. [CrossRef]

95. Kozikowski, A.P.; Kotoula, M.; Ma, D.; Boujrad, N.; Tuckmantel, W.; Papadopoulos, V. Synthesis and biology of a 7-nitro2,1,3-benzoxadiazol-4-yl derivative of 2-phenylindole-3-acetamide: A fluorescent probe for the peripheral-type benzodiazepine receptor. J. Med. Chem. 1997, 40, 2435-2439. [CrossRef] [PubMed]

96. Breitinger, H.-G.A.; Wieboldt, R.; Ramesh, D.; Carpenter, B.K.; Hess, G.P. Synthesis and characterization of photolabile derivatives of serotonin for chemical kinetic investigations of the serotonin 5- $\mathrm{HT}_{3}$ receptor. Biochemistry 2000, 39, 5500-5508. [CrossRef]

97. Smith, P.K.; Krohn, R.I.; Hermanson, G.T.; Mallia, A.K.; Gartner, F.H.; Provenzano, M.D.; Fujimoto, E.K.; Goeke, N.M.; Olson, B.J.; Klenk, D.C. Measurement of protein using bicinchoninic acid. Anal. Biochem. 1985, 150, 76-85. [CrossRef] 